\title{
34
}

\section{On Certain Limitations \\ of the Thoughtful Public \\ in America}

No one who is engaged in any part of the work of the higher education in this country can doubt that, at the present time, our thoughtful public,--the great company of those who read, reflect, and aspire,-is a larger factor in our national life than ever before. When foreigners accuse us of extraordinary love for gain, and of practical materialism, they fail to see how largely we are a nation of idealists. Yet that we are such a nation is something constantly brought to the attention of those whose calling requires them to observe any of the tendencies prevalent in our recent intellectual life in America.

\section{I}

When I speak, in this way, of contemporary American idealists, I do not now specially refer to the holders of any philosophical opinions, or even to the representatives of any one type of religious faith. I here use the term in no technical sense. In this discussion, I mean by the word "idealist," a man or woman who is

An address first delivered at Vassar College. [Reprinted from RQP, pp. II I - 65.] 
consciously and predominantly guided, in the purposes and in the great choices of life, by large ideals, such as admit of no merely material embodiment, and such as contemplate no merely private and personal satisfaction as their goal. In this untechnical sense the Puritans were idealists. The signers of our Declaration of Independence were idealists. Idealism inspired us during our Civil War. Idealism has expressed itself in the rich differentiation of our national religious life. Idealism has founded our colleges and universities.

Well, using the term "idealism" in this confessedly untechnical sense, I say that many of our foreign judges have failed to see how largely we Americans are to-day a nation of idealists. To be sure, we are by no means alone amongst modern men in our idealism. But elsewhere sometimes the consequences of long-continued and oppressive militarism, sometimes the stress of certain social problems, and sometimes the burdens of ancient imperial responsibility, have tended more to discourage, or even quite to subdue, many forms of that fidelity to ideals upon which surely all higher civilization in any country depends. But, with us, ever since the close of the Civil War, numerous forces have been at work to render us as a nation more thoughtful, more aspiring, and more in love with the immaterial things of the spirit, and that too even at the very moment when our material prosperity, with all of its wellknown corrupting temptations, has given us much opportunity, had we chosen to take it, to be what the mistaken foreign critics often suppose us to be,-a people really sunk in practical materialism.

Moreover, in saying all this, as to our general growth in spiritual interests, I am not at all unmindful of that other side,--that grosser material side of our national life, upon which our foreign critics so often insist. The growth of unwise luxury, the brute power of ill-used wealth, the unideal aspects of our political life, the evils of our great cities,-what enlightened American is there who does not recognize the magnitude of such ills in our midst? But you cannot prove the absence of light merely by exploring the darker chasms and caverns of our national existence. Vast as are those recesses of night, the light of large and inspiring ideas shines upon still vaster regions of our American life. Side by side with the excesses of mere luxury you find, amongst our people, a true and increasing, a self-sacrificing and intelligent love of the beautiful 
for its own sake. Side by side with the misuse of money, you observe the encouraging frequency of the great and humane deeds that wealth can do. Nor is this all. An ardent and often successful struggle for social reform, and a civic pride that aims, sometimes even from the very depths of municipal degradation, at the accomplishment of great and honorable public services,-these are tendencies that are growing amongst us, and that are never wholly or permanently checked even by the closest contact with the very worst of our national defects.

Yet, of course, the real proof of the prevalence of what I have called idealism, in the great masses of our people, is above all to be sought not in any particular good deeds of wealthy men, nor yet in the public life of the great cities, but in the intellectual and religious life of the community at large. And here it is, as I say, that the college teacher, or any other worker professionally concerned with the higher mental interests of our people, has a chance to estimate the strength and magnitude of these interests in the unseen.

In our country it is extraordinarily easy, and as one may at once admit it is too easy, to get a hearing for any seemingly new and large-minded doctrine relating either to social reform or to inspiring changes of creed. Whoever desires the reputation of the founder of a new sect has merely to insist upon his plan for reforming society and saving souls,--has merely to announce repeatedly to the public the high valuation that he sets upon his own ideas concerning nobler topics in order to win a respectful hearing from many, and, if his ideas have any measure of coherence and of humanitarian interest, an often all too kindly acquiescence from at least a few. And the faithfulness of these few may soon assume the pathetic intensity that so often marks the devotion of the followers of small sects. Need I mention many instances in order to remind you of the nature of these now so familiar processes in our American life? The late Mr. Henry George was, up to the time of the appearance of his "Progress and Poverty," a man quite unknown to the nation at large,-a California newspaper man, with no obvious authority to teach concerning economic problems. His book received, at the time of its appearance, little or no support from the professional economists, and excited at first, I believe, little very close attention from their side. George himself was no party manager. He used hardly any showy devices for attracting popular attention. He was simply in 
earnest. Yet we all know how the sect of his followers grew. And any busy man who has sometimes received letters from propagandists of that particular sect will also know, I suppose, how humane, how faithful, how strenuous, how unworldly, and one may add, how unweariedly obstinate they may be in their efforts to convert the doubter and to lead people to see, and if possible to love, their new way of social salvation. A similar, and even more swiftly contagious kindliness made possible the dramatic, if temporary, success of Mr. Bellamy's book, "Looking Backward." And again, a case in point is the movement in connection with which Bryan gained his first national prominence in 1896 , a movement which came near proving successful, and which was then for a time so dangerous. That movement had its origin quite as much in practical idealism as in material distress. Its fundamental motives were in considerable measure philanthropic, humane, and, in an abstract way, vaguely large-minded. That was precisely what made this movement most dangerous. Unwise philanthropy, uninstructed largemindedness, can often prove injurious to the very interests they seek to further. Our greatest national danger now lies in an extravagant love of ideally fascinating enterprises, whose practical results are as hard to foresee and to estimate as was the end that lay before the noble-hearted Childe Rolande of Browning's wellknown poem, when he searched for the goal of his journey in the midst of the shifting landscapes, and the treacherous pathways of his romantic wilderness.

Well, these, I say, are instances of our American idealism in social matters. In religion, a similar tendency has been strong in our life from the very first. It has not only multiplied sects among us, but it has also wrought great good by giving lasting strength to their missionary and to their other philanthropic enterprises. Moreover it has endowed them with an importance for the daily life of the people that no established State church could ever have won by a merely external show of authority. The same interest in ideals has kept the sects themselves from stagnation, has insisted upon an adjustment of whatever in their fashions of teaching was non-essential to the vital needs of each generation of people. On the other hand, this idealism often shows itself less worthily in the form of a hasty desire for whatever seems new, or remote, or fantastic in faith. At the present day there is hardly a conceivable creed about ultimate matters, be it never so quaint 
or so unreasonable that, if its apparent intents are only humane, and its catch words impressive, this creed once earnestly taught cannot very quickly find a body of adherents, not only in our country at large, but in some of the most thoughtful and sophisticated communities which our country contains. It is not the ignorant amongst us who are the prey of strange new doctrines, so much as a portion of the most considerate classes of our public. And we are indeed not obliged to be bigoted in order to feel that, at present, this spiritual plasticity of our American public has gone too far. We ought to be docile; but the disposition to prove all things can easily outrun the power to hold fast that which is good.

As a consequence, if new sects thus easily find followers, and often faithful and permanent followers, there is also the other side of the picture. There are those of our people who waste life in merely floating from doctrine to doctrine. In such minds the art of holding fast has wholly been lost, in favor of the easier art of at least playing with all the things that belong in the realms of the spirit. For such souls, new doctrines are like new pictures, or new plays, or like the passing events of a social season. The more ardent amongst such people grow temporarily enthusiastic upon every new occasion where they listen to what they cannot comprehend. The more disillusioned find the novelties in doctrine more or less of a bore, just as some folk always find the plays and the parties tedious. But both the ardent and the disillusioned, in such social groups as I now have in mind, do indeed treat the new doctrines and the various rival plans of salvation altogether too much as they treat the social occasions, the plays, or the pictures. They expect something new to take the place of the old at each moment of their experience. And whether ardent or bored they continue their life-long quest for spiritual sensations.

Such excesses of the higher life in our country are only too easy to observe and, upon occasion, to ridicule. I have not mentioned them however for the sake of ridicule. Spinoza said that human affairs are neither to be wept over nor to be laughed at, but to be understood; and Spinoza's word, despite its seeming fatalism, had from any point of view its large measure of truth. I am speaking at present of symptoms. These symptoms, like other incidents of so complex a life as ours, have both their good and their evil aspects. Devotion to ideals has its dangers as it has its 
glories. I have to point out the one as an aid toward a comprehension of the other.

I turn to still other and better aspects of the tendency here in question. If one asks what the devotion to ideals has of late accomplished with purest success in the intellectual life of our country, I myself should be disposed to name, as one of the noblest, most positive, and most unsullied products of American idealism in recent years, the whole modern educational movement. The reform of academic methods and interests, both in the younger and in the older universities and colleges has been such, within the past twenty-five years, as to constitute one of the most substantial and significant events in our national history. The general public still understands all too little of the vast work that has been accomplished. By the fault of too large a portion of the newspaper press of the country the more trivial aspects of our academic life,-the public athletic contests, and the idle gossip of the hour,-are continually exaggerated, while the serious and the most progressive tendencies of this same life are as persistently slighted and are often misrepresented. Yet despite the false perspective in which our colleges are thus often made to appear, the general public has nevertheless somehow learned to support nobly the interests of academic reform. The vast sums that have been dedicated to the cause of learning, the cordial approval that our more enlightened people have given to the attempts at bettering higher education,these have been most encouraging features of our educational movement. Nor has this movement confined itself to the Universities and Colleges. In its connection with the lower schools it is still in the period of storm and stress and hope. But it is indeed, in all its forms, a movement in the interest of ideals. It has needed at every step great sacrifices, strenuous devotion, wide sympathies, and far-reaching foresight. And these have been forthcoming. When an intelligent American wants to vindicate the honor of his country to foreigners, I know in our recent history of no purer instance of single-hearted patriotism, devoted to humane and unsullied ideals, and successful against all sorts of foes, not only without but within,-I know, I say, of no purer instance of such true patriotism than is furnished by just the great educational reform movement, and especially the academic movement of the last quarter of a century. For this has indeed been no mere effort of dreamers. It has been a practical movement. It has been guided 
by administrators who were often of the highest executive talent,men quite capable, in many instances, of winning worldly success in wholly different and more showy regions of public life. It has been supported by benefactors who were often tempted by all sorts of more selfish interests to use their wealth otherwise. It has given to great numbers of youth a light and guidance that have meant for them escape from spiritual bondage, and an opportunity to become in their turn benefactors. It has furnished to our country a constantly increasing class of cultivated workers, ready to enter practical life with the ardor of a genuine idealism in their hearts and minds. And great as this academic movement has been, its influence is only beginning. Its real fruits are still to be gathered.

So far, then, I have surveyed a number of forms of recent American idealism. I have meant to be fair to both sides of the shield. Not all golden is our devotion to ideals. Yet this devotion is too marked a feature of our national spirit to justify the neglect of those among our foreign critics who regard us as mainly workers for wealth, or as lovers of mere material power. It may not be unfitting, upon this occasion, for us to ask ourselves what can yet be done to make our national idealism more intelligent, better organized, and, above all, more effective.

\section{II}

For, after all that we have thus far said, when we try to sum up the amount of influence exerted by these various forms of idealism upon the actual life of our country, we are obliged to confess that our thoughtful public is not yet as efficacious as it ought to be. Too frequently we find the lovers of the ideal engaged in unprofitable conflicts with their spiritual kindred. Plan wars with plan; reform stands in hostile array over against reform. Meanwhile the children of this world are wiser in their generation than the children of light. The people who dwell in the realms of thought and of higher faith consequently find themselves unable to organize effectively their reforms. They indeed associate, discourse, and take counsel together. But their enemies remain too often the better managers. While, as I just said, the academic movement is the great instance amongst us, in recent times, of the possible practical success of ideal interests, this educational progress stands too 
much alone. Our tree of life flourishes, and puts forth countless leaves; but it does not yet bear sufficient fruit for the healing of the nation. Our national idealism is more characteristic of our intellectual and religious life than it is productive of permanent, organized, and substantial results. Whenever the servants of ill perfect their devices for corrupting anywhere the state, and misusing its resources, the lovers of good things find themselves too frequently helpless to thwart such mischief. Yet amongst us the conscious servants of ill are really in a very decided minority. Our youth are exceptionally high-minded and aspiring. Our social life is full of admirable purposes. Our people are very generally interested in the things of the spirit. Yet the enemy seems to have possession of far too many of the effective weapons of social and of political warfare. When we try to meet him in the field, we are too scattered, too fantastic, or too uncertain in mind, to be ready for an effective fight. Our thoughtfulness involves too much idle curiosity, too much vaguely restless ardor, too much unwillingness to accept the necessary material limitations under which human work is to be done. And therefore we are indeed often, in practical undertakings, "beaten down" like Tennyson's Lancelot in his quest for the Grail, "beaten down by little men, mean knights." The enemy, the power of evil at work, in whatever form in our land,-the enemy at least always knows his own purpose. But we, we lovers of the ideal, spend far too much of our time vaguely wandering from one club-meeting or lecture or recent book to another, trying to discover just what it is that we are thinking about. While we, with eager minds, inquire into the shifting thing sometimes called the New Thought, the enemy is steadily engaged in serving the purposes of the Old Adam. And those purposes need no course of lectures to define them, no laborious clambering toward any "higher plane" to survey them. The devil within is always ready to explain them directly and personally to all comers. The consequence is precisely that appearance of grosser materialism which our foreign critics falsely take to be characteristic of our country. But much more characteristic of us is the intensity, the manifoldness, the restlessness, and in all but a few regions, the relative ineffectiveness of our national idealism.

Look where you will, even in the regions where ideas best and most beneficently express themselves in our social life, and you find the same limitations of our thoughtful public exemplified, setting 
bounds to our spiritual progress even in the best regions of our activity, and resulting in too many cases, in a more or less complete inability to do wholesome reforming work where work is most needed. In speaking thus, I have in mind no one section of our country, no one type of activity, no one special class of our thoughtful public. As myself a Californian, and as one often called upon to visit, in connection with professional duties, very various parts of our land, I have felt the limitations of which I speak in the West as well as in the East, amongst good men and women, in the life of the professional classes as well as in the life of the people of the world.

Wherever you go, you find the typical American sensitive to ideas, curious about doctrines, concerned for his soul's salvation, still more concerned for the higher welfare of his children, willing to hear about great topics, dissatisfied with merely material objects, seeking even wealth rather with a view to its more ideal uses than with a mere desire for its sensuous gratifications, disposed to plan great things for his country and for his community, proud of both, jealous of their honor, and discontented with the life that now is. His piety has its ideal fervor none the less when it is the piety of the free thinker than when it is that of the faithful. He forms and supports great associations for public-spirited ends. He encourages science and learning. He pauses in the midst of the rush of business to discuss religion, or education, or psychical research, or mental healing, or socialism. His well-known and characteristic devotion to his children keeps fresh in his heart a childlike love of plans and hopes and beliefs that belong not so much to the marketplace, as to the far-off future, and to the home land of the Platonic ideas.

Yet this same American is unable to give his idealism any adequate expression in his social life. His country towns and his manufacturing cities are too often full of hideous ugliness. Even the best of his great cities are in appearance whatever they happen to be. In founding new cities and in occupying new lands he first devotes himself to burning the forests, to levelling with ruthless eagerness the hill-slopes, to inflicting upon the land, whatever its topography, the unvarying plan of his system of straight streets and of rectangular street crossings. In brief, he begins his new settlements by a feverish endeavor to ruin the landscape. Now all this he does not at all because he is a mere materialist but (as a 
colleague of mine, Professor George Palmer, has pointed out), he does this because mere nature is, as such, vaguely unsatisfactory to his soul, because what is merely found must never content us, and because our present life itself is felt to be not yet ideal. Hence, the first desire is to change, to disturb, to bring the new with us.

In the regions thus so quickly altered by man's hand, a community spirit, a strong local pride, quickly springs up. The church, the school, the university, appear within a very few years, and seem at first as if they were quite at home. One is firmly determined, in each young community, that they shall all be the best of their kind anywhere to be found. The social order thus established has also its representative literature,-its poets, its artists, its public heroes, even its swiftly acquired local traditions, as well as its selfconscious social independence, somewhat too ardently and tremulously asserted, of the mere wornout ideals and authority of the older regions of the country.

Nor are the interests in ideal things confined to such expressions. Confident faith in the future and in the might of the new life asserts itself in such newer regions of our land in the overhasty construction of great railways, that pierce the mountains or invade the deserts, long before a less restlessly ideal people would have seen sufficient prospect of any adequate return for the material outlay. Our pioneer makers of railways have often seemed as if they were themselves amongst the prophets, the poets, or even the fanatics of our newer communities. But the result of this eagerness is too often a swift bankruptcy. The young community flies too near the sun, and then lies prostrate and wingless in the despair of hard times.

Hereupon begins the grosser period. The community soon really possesses through mere accumulation more wealth and power; yet merciless money-getters have profited by the failures of the first period, and these now take possession of the creations of the pioneers, crush out weaker opponents, obtain too much influence in local politics, and give to the life of the community just that outward seeming of mere materialism of which we have spoken. And now the better men learn more thoughtfully to look about them, only to observe, at this stage, what vast opportunities have been lost, what noble natural beauties have been hopelessly defaced, what ideal kingdoms have been carelessly created only to be conquered by the enemy. 
The real struggle with evil herewith begins. The social order, so hastily and easily organized at the outset, through the finely ideal political instincts of our people, now becomes infected by various political diseases. Corruption grows too prominent in politics. The Philistines seem to have captured and blinded the Sampson whose deeds made the pioneer days so wonderful. Satan seems to have triumphed.

Yet this triumph is never so real as it seems. The good are still in the majority. The heart of society is still healthy. The church, the school, the university, the public library, the literary circles, the intellectual clubs,-these not only remain, but multiply, and in these one finds centres for the propagation of ideal interests. Would-be reformers become numerous. But alas, they war among themselves. They are too often crude, strident, prejudiced. Greed too often wins possession of the strongest material forces of the community. The reformers lift their too familiar voices in vain. The prophets true and false speak their many words. Many listen and applaud. Yet at the elections the prophets do not win. The thoughtful public remains the most characteristic, but too often the least effective, portion of the community.

Such is the tale of too many of our newer communities. Shall I speak still of the older communities? There indeed the processes are more complex; but the lesson, like the outcome, is too often the same. The great limitation of our thoughtful public in America remains its inability to take sufficient control of affairs. And in pointing out this limitation, I have already indicated, in a measure, both its causes and the directions in which we ought to look for a cure, if a cure is possible, for this ineffectiveness of our American idealism. Let me pass then to a closer study of this latter aspect of the case. I have not undertaken this discussion for the sake of merely criticising my brethren; but for the sake of suggesting some few ways of improving our state, in so far as any poor suggestions of mine can hope to possess value.

\section{III}

Yet, as I go on to this side of our topic, I must indeed admit quite freely that I have no panacea, no quack remedy to suggest, as any infallible cure for the ineffectiveness of our national idealism, or as any one saving device for overcoming the limitations of our 
thoughtful public. Such ills as the one here in question always lie deep in the very constitution of our temperaments. We cannot, by merely taking thought, add a cubit to our stature. One of the very limitations of our thoughtful public which are here under discussion lies in the fact that many of us suppose great reforms to be possible merely through good resolutions. Yet good resolutions have their place in accomplishing reforms. Our mere human consciousness never by itself transforms our temperaments; but it may do something toward lessening their ill effects, and toward intensifying or enlarging the range of their good qualities. Where limitations have to be overcome, a due measure of consciousness as to where the fault lies does not come amiss. Accordingly, with a full sense of the little that I can do by such mere practical advice as lies within my scope, I still wish not merely to point out the ailment, but to show how it may be attacked. That it is no hopeless ailment, such successes of our idealism as the modern educational movement have already shown us. May we not hope to escape in time and at last, in a measure from the ineffectiveness that now besets the efforts of the thoughtful people of our country?

Reform, in such matters, must come, if at all, from within. The kingdom of heaven is within you; and that truth is precisely what all ideally minded people know. It is this knowledge which makes them lovers of the unseen. I cannot then offer any pedagogical device for raising the thoughtful public of our country to a higher level of effectiveness, unless my device appeals directly to the individual. The public as a whole is whatever the processes that occur, for good or evil, in individual minds, may determine. No one of us is individually called upon for any very large share in determining other peoples' lives. The work of any one man, in this life, has a narrow range. Yet, on the other hand, the forest is made of the trees; and great reforms are due to the combined action of numerous individuals.

I appeal then to the individual lover of ideals. I say, upon such as you are, and upon such as you aspire to be, the future of our country depends. If you fail, in union with your spiritual kind, to win, and to win for good, the controlling voice in the nation's affairs, corruption, grossness, despotism, social ruin, will sooner or later make naught of our liberties, of all the dear memory of our country's fathers, and of the great work that we in America 
ought to do for mankind. And if such as you are find not the way to overcome, in time, these present limitations of the effectiveness of our thoughtful public, you will fail to win and to retain control of the constantly increasing complications of our national life. Our ideals will grow vaguer and more restless, even while our material activities become more steadily enchained by the powers of evil. We shall end where others have ended, in national disaster, in social dissolution, in humiliation, in the clutches of some domestic or foreign conqueror.

But in case you win effective control over your personal ideals and over your own processes of giving them expression, you yourself as an individual will indeed accomplish but an infinitesimal portion of the nation's vast task. Yet still it will be the nation's task in which, in your measure, you will be engaged. For no man liveth unto himself, and no man dieth unto himself. I appeal then to you, and to the public, only through such as you are. If you, together with the others who love the coming of the kingdom of heaven, succeed in solving your personal problems, the good cause will win in public as in private. And what you need to find is some little task that you can effectually do. That task you need to perform.

To the individual, then, I address myself. Nor do I forget that I am speaking to students who already know what one means by high ideals, and by hearty aspirations, and who stand at the beginning of life's great tasks. There comes a sad time in many lives, when people who have long struggled in vain with foes without and foes within, grow weary of the cultivation of ideal interests. Those to whom I am especially privileged to speak, upon this occasion, have not reached this stage. I hope that when any of you reach it, you will pass it successfully, for nothing better have we in this life than our ideals and our hopes, and our power to do a little work. Just now you are privileged to have a faith, still unsullied, in such ideals, and a hope to do good work. I want to indicate some of the ways in which one may wisely nourish this faith, and undertake this work.

\section{IV}

My first word of advice, addressed thus especially to the thoughtful amongst us, relates to a certain moderation, to a certain tem- 
perance, that, as I believe, we must all cultivate in dealing with our own consciousness of what our ideals are. Devotion to what we believe to be a high cause demands of us, indeed, a certain thoroughness of surrender, a certain persistence in service, which, in its own due time and place, ought to know indeed no bounds. On the other hand, when thoughtful people cultivate ideals, they do so, in part, by thinking over these ideals, by reasoning about them, by becoming conscious of what they are, by trying to convert others to these ideals, and, in general, by giving these ideals articulate expression. The faithfulness of the unlearned may be dumb, half-conscious, incapable of giving any reason for itself. The fidelity of the thoughtful seeks definite formulation in a creed, propagates its cause by spoken and by written words, voices itself in a doctrine that can be defended or assailed by argument,-in brief, seeks to add knowledge to faith, insight to service, and teaching to example. You often hear how important it is to be not only devoted, but wise, clear of head as well as persistent in service. Now such tendencies are an important factor in the lives of all thoughtful people. Their highest expression is a reasoned philosophy, which undertakes to investigate, to compare, to harmonize, and then, finally, to formulate and to teach systems of ideals. Now I am myself by calling a teacher of philosophy. I believe in persistent thoughtfulness as a most important factor in the higher life of humanity. I try to become as conscious as I properly can become of what my ideals are, and of why I hold them, and of how they go together to make one whole, and of why other lovers of reason ought, if I am right, to accept my ideals. Over against the inconsiderate partisans of this or of that form of unreasoning faith, I often have, as teacher of philosophy, to maintain the importance, for certain great purposes, of giving a reason for the faith that is in us. And so, as you see, I am in every way disposed to favor, in its place, not only the thoughtful spirit of inquiry, but the disposition to formulate ideals in a definite and conscious way, to maintain them through argument, and to propagate them by the spoken and by the written word. I believe in the human reason, as a vastly important factor in the development of all our ideals.

And yet,-I can here speak all the more frankly just because my profession is that of the reasoner,--I constantly see mischief done by an unwise exaggeration of the tendency to reason, to argue, to trust to mere formulas, to seek for the all-solving word; in brief, to 
bring to consciousness what for a given individual ought to remain unconscious. Thoughtfulness is, for us in this life, like any other human power and privilege. It must be exercised with a proper moderation. Thought must indeed be free. But freedom means responsibility. Thought in any individual, must freely set limits to its own finite task. And when the thoughtful lovers of ideals forget this fact, they may become mere wranglers, or doctrinaires, or pedants, or, on the other hand, in the end, through failure in thinking, they may become cynics. Now some may wonder that, as a teacher of philosophy, I should at once lay the first stress upon this defect of the lovers of ideals, as a defect so often attendant upon the processes of unhappy thinkers. Some may wonder that I first confess the errors of my own calling. Yet why should I not do so? What defects has one more occasion to observe than those which occur in the erring human effort to pursue his own calling? If one loves his calling and believes in it, does he therefore ignore these defects? Shall one make a business of the art of seeing clearly, and yet entirely ignore the imperfections that may naturally beset his own organ of vision?

Very well then, I first observe that many thoughtful lovers of ideals, many students, many reformers, many teachers, are too much disposed to trust to constant argument, reasoning, or reflection, to keep them faithful to their own ideals, and to win others to these ideals. Or again, some lovers of the ideal, even when they profess not to argue, but to be followers of intuition, still in many cases are too fond of abstract formulas, of catch words or phrases. Such mistake fads for eternal truths. Now all such have not observed the inevitable limitations of the human thinking process in each individual mind. They do not observe that any one of us can think clearly and reflectively and can formulate exactly and successfully only in case we think with due moderation, and think during the time properly set apart for thought, trying to formulate only what we have more or less expert right to understand, and then devoting the rest of life to näiveté and to relatively unreflective action. As a professional reasoner, I have a profound contempt for deliberate excesses in the work of reasoning; I personally try to avoid such excesses. As one busy with formulating theories, I have a great hatred for the excessive use of formulas.

I remember well, from my student days, a pathetic incident that may illustrate the spirit in which I make this confession. While 
I was studying philosophy, one winter at Leipzig, I enjoyed many happy hours in company with a musical friend of mine, an advanced student at the Conservatory, who had devoted himself since childhood to the violin, and who has since won an important place in his profession. He often took me to attend the musical evenings at the Conservatory, and so helped me, as a mere listener, to enter the wondrous world of tones where he was making his home. But alas! for the moment, my friend, although so faithful and advanced a student of music, was himself no public performer at the Conservatory evenings, although in previous years he had been a prominent and favorite student player. Overwork had given him, for the time, one of those well-known functional nervous troubles of coördination, or "occupation disorders"; namely, in his case, a "violinist's arm." Neuralgic pains whenever he played had forced him to suspend his efforts. Prolonged rest for his arm was needed. My friend was perforce spending this year in the study of musical theory, and in other more general intellectual tasks relating to his art. Naturally this forced restraint was hard, and wounded ambition would often express itself; but still my friend was a man of general mental skill, who had therefore not a few resources in his distress. One evening we were together at the Conservatory. Many students played. Among them my friend's principal contemporary and rival, a young violinist of no small skill, won abounding applause by a very brilliant performance. And my friend, sitting beside me with wounded wing, must merely listen! It would have been more than human not to rebel a little. But my friend could at least remember that he himself had his own variety of mental occupations. He did remember this fact, yet he grieved inwardly and deeply. As we were walking home he was silent for a time, and then his wrath at the chains that bound him burst forth. We spoke of the rival. We could not avoid the topic. "Confound that fellow!" said my friend. "Confound that fellow; he can't do anything but fiddle!"

Well, I speak somewhat in my friend's general spirit, although I hope without any bitterness toward any particular rival student when I now say: "I am indeed not nearly as much of a reasoner as I desire to be. My skill in this art is far below my ambition. But, poor as I am, reasoning is indeed my own art. I love it. I prize it. I cultivate it. It is a great part of my life. And yet,-and yet I still insist,-let that reasoner, that thoughtful lover of ideals, that philos- 
opher, if such there be, let him be confounded who cannot do anything but reason." And in the same way I say to you of the thoughtful public: Woe unto the man or woman who can do nothing but be thoughtful.

Yet why do I thus warn you? Pedantry, it will be said, is a disease of professors and of bookish men. The young, the ardent, and the general company of the faithful to ideals in our land, whatever their faults, are surely not pedants. An overcultivation of the merely abstract reason is not a besetting sin of most people. I reply that there are many forms of pedantry; there are many grounds for being on one's guard against it. The misuse of the reasoning process enters the life of the thoughtful in more ways than one. The love of abstract formulas, of mere phrases, or of falsely simplified thoughtful processes is not confined to the professors.

I remember once discussing with a young lady who was a college student of psychology, some points in the text-book of my honored colleague Professor William James. We spoke in particular of his wonderful chapter on Habit, so full, as some of you may know, not only of theoretical wisdom, but of wholesome practical advice about the formation and control of habits. I asked my young friend what she thought of this chapter. She replied, with adorable naïveté, that she had found this chapter full of advice which must be very valuable indeed "for the young men for whom it was intended." Well, my young friend had certainly observed part of the significance of Professor James's chapter; but she did not admit having observed that his comments upon Habit apply to us all, whether young men or not. And now, just so, I should be sorry to have my word about the misuse of reason and the false love of abstract formulas supposed to apply only to those philosophers, if such there be, for whom it was indeed also intended. The lesson is general, and human. Especially does it apply to all the thoughtful public of America.

For this fault of a too abstract thoughtfulness is committed, in substance, whenever people try to reform all the world, or even any great region of our complex lives, by insisting upon any one set of phrases, of human conceptions and words, which the individual himself has found somehow dear to his own consciousness. Not merely the partisans of technical reasoning, but the apostles of intuition, too, can commit our fault, whenever they trust in any mere abstraction. The people of one idea, the people to whom this 
or that single device for saving souls is alone important, the followers of fads,-these fall prey to this form of error. They mistake the power to define for the power to accomplish, the abstraction for the life, the single thought for all the wealth of truth that our human world contains, the exercise of an individual reason for the whole task of reforming our nature. And does not our modern America, both in the East and in the West, really suffer too much, nowadays, from mere fads? What shall I do to be saved? says the inquirer,-and the answer is,--"Practice this or that system of mind cure, whose teaching can be made clear in just so many lessons. Follow Delsarte, study your attitudes, or oratory, or some other formal accomplishment. Accept this or that doctrine of the New Thought." Now the people who cultivate ideals in this spirit often suppose themselves to be free from the philosopher's overwrought love of the reason. "We follow," they say, "spiritual intuitions. We thus avoid abstractions and wrangling." "Yes," one may reply, "but you none the less are anxious for some all-embracing formula, some one saving principle that shall do all manner of work." Now the human mind, in its present form of consciousness, is simply incapable of formulating all its practical devices under any one simple rule. We have to learn both to work and to wait. We have to learn to obey as well as to formulate. What saves the world can never be any one man's formulated scheme. Restless search for the immediate presence of the ideal is often vain, like the pioneer idealism that burns the forests merely to see what they hide. Let the forests grow. They are better than the empty hillsides. Much of the best in human nature simply escapes our present definitions, is known only by its fruits, and prospers best in the forest shade of unconsciousness. But a thoughtful lover of ideals, whether a philosopher or not, is of course thinking of something that he can formulate,-is trying to make his ideas conscious, explicit, teachable, and so abstract. Hence so much of his life's business as he best formulates is likely for that very reason to be narrow when compared with his whole human task and with his own best and deepest aims. We are primarily creatures of instinct; and instinct is not merely the part of us that allies us with the lower animals. The highest in us is also based upon instinct. And only a portion of your instincts can ever be formulated. You will be able in this life to tell what they mean in only a few instances. But your life's best work will depend upon 
all of your good instincts together. Hence a great part of your life's work will never become a matter of your own personal and private consciousness at all. It is one of the duties then of the thoughtful lover of ideals to know that he cannot turn into conscious thinking processes all of his ideal activities. Accordingly, he must indeed cultivate a wise naïveté, and that alongside of his reflective processes. That is why the companionship of children becomes the more useful to us the more thoughtful we are. They show us the beauty of unconsciousness, and help us to compensate for our tendency to abstraction by reminding us of what it is to live straightforwardly.

And now, I say, this rule of mine applies to the very lover of ideals whom I now chance to be addressing. We who teach philosophy are constantly receiving inquires from people who seem not to know how little in human life can as yet be reduced to any abstractly stateable formulas at all. Teachers inquire as to the final and correct theory of the development of the human mind, as to the precise number of powers that the mind possesses, or as to the one secret of method in education. Newspapers or magazines call for popular discussions of the most serious and complex issues, as if these could finally be dealt with in any brief shape. A newspaper once asked me to contribute to a so-called symposium whose problem was to be this: What characteristics will the ideal man of the future possess? As I only knew about the ideal future man this, that when he comes, he will, as in him lies, adequately attend to his own business, I felt unable to contribute anything original to the proposed discussion. The first condition of knowing how to think about ideal subjects consists in being aware not only what can be profitably formulated at all, but when and for what purpose a given formulation is profitable. When I visit a convalescent friend who is beginning to feel joyous after a long illness, I do not in general discuss the problem of evil. When I too am to enjoy the company of my friend, I do not first undertake to inquire into the metaphysical problem as to whether my friend exists at all. And yet just such problems have their place in philosophy. Now just so, when I vote, since, as it chances, I am no expert in sociology or in economic problems, I generally have no really very good reason that I can formulate, in a conscious and philosophical way, why I vote just as I do. I vote largely on grounds of sympathy and of instinct. I know better than to try to do otherwise. If I tried to 
formulate a political theory, it would be a very poor one; for I have no scientific comprehension of politics, no philosophy adequate to directing my choice of parties. For my business is largely with other branches of philosophy. I am a member of one or two deliberative bodies, where I often hear lengthy debates upon complex practical questions. The debates for a time instruct me; but later they often weary me, if they continue, without instructing me. When people ask me my reason for my own vote in such complex practical cases, or wonder why I am anxious for a vote to be reached, I often say that just because my profession is reasoning, I have learned to know some of the limits of the art, and to recognize that about some complex practical issues, after a certain point, it is vain to reason further, since only personal reactions, incapable of adequate reflective formulation, will decide. Hence I grow weary of the much speaking. I know that at such times I seem unreasonable; but I merely want to vote; and more formulations will in such cases make me no wiser.

People often say that men act upon conscious reasoning processes, and women upon intuitions which they refuse to formulate. The assertion is, like most proverbial assertions, inadequate to the wealth of life's facts. Certainly women often enough act with a mysterious swiftness of unconscious wisdom. But so do many of the most effective men. I have, however, often observed that some educated women, some women who enter public life as reformers, and perhaps too many college-bred women, are nowadays troubled with an overfondness both for mere formulas and for abstract arguments about complex practical issues that only a happy instinctive choice and wholesome sentiment can ever successfully decide so long as we remain what we are; namely, frail and ignorant human beings, who see through a glass darkly. The fault of being overfond of abstractions, or of trying to formulate bad reasons for one's instinctive actions, does not characterize the man of business or the successful executive. One does not meet this fault in the market-place. But just this fault does characterize some of our most cultivated and thoughtful people in this country. And among these people I find a good many intellectual women.

What then is the happy medium? Shall I cease to think? No, not so. Be thoughtful, reason out some of your ideals for yourself. Know something, and know that something well. Have the region where you have a right to mistrust your instincts, to be keenly 
and mercilessly critical, to question, to doubt, and to formulate, and then devotedly to maintain and to teach. But let that region be the little clearing in your life's forest,-the place where you see, and comprehend, and are at home. Let there be such a place. You need it. It may be art, or theology, or Greek, or administrative work, or politics, or philosophy, or domestic economy, or general business, wherein you find this your chosen intellectual dwelling. In that region be indeed the creature of hard-won insight, of clear consciousness, of definite thinking about what it is yours to know. There the formula is in order. There the ideal is won by your investigations, and defended by your arguments. I say, have such a region. We need those who know. In that region, believe only when you know why you believe. But remember, life is vast, and your little clearing is very small. In the rest of life, cultivate näiveté, accept authority, dread fads, follow as faithfully as your instinct permits other lovers of the ideal who are here wiser than you, and be sure that though your head splits you will never think out all your problems, or formulate all your ideals so long as you are in this life. If this precept were followed in this country there would be more experts, and fewer popular crazes, more effective work done, and less time wasted in hopeless efforts at general reforms. De te fabula, I say to every studious soul who is disposed to be too thoughtful rather than wisely effective. Be in your devotion to effective leaders relatively uncritical in many things, in order to be thoughtfully knowing in some. Be childlike in much of life in order to become maturely wise in some things.

\section{$\mathbf{V}$}

If you are once aware of the vanity of trying to formulate everything, and to argue about all sorts of problems, you will not be tempted to pursue unwisely mere novelties of formulation for their own sake. I have spoken more than once of the feverish desire for new ideas in which our thoughtful public wastes much time. An entirely false interpretation of the doctrine of evolution has led some people to imagine that in any department of our lives, novelty as such must mean true progress toward the goal. Hence you constantly hear of the New Education, the New Psychology, the New Thought, the New Humanity, and whatever else can be adorned by the mere prefixing of this adjective. And yet people 
do not speak adoringly of the New Blizzard, or of the New Weather in general. We all of us have a fondness, not altogether wise, for the so-called news of the day, quite apart from its meaning; and the newspapers daily verify for us the ancient fact that bad men lie and steal and murder. Such news, which alas is no news, but the ancient sorrow of our race, we do indeed greet with a certain keenness of interest which is neither altogether rational nor highly ideal. But still the lovers of the ideal do not in such cases suppose that some new form of burglary must, because of the fatal law of evolution, be higher in nature, or nobler, or more worthy of study than the older arts of the thieves. So nobody preaches in praise of the New Burglary. Nor do we suppose that evolution implies, as any universal law, that the New Blizzard, when it comes, is an object worthy of admiration above all former caprices of our climate. We know that if news, in this sense, is indeed interesting, still the weather is the weather, and the thieves break through and steal, and that no news makes more ideal these ancient aspects of the visible world. Now much that is proposed as new in thought, or in the less exact sciences, or in complex arts such as education, has indeed its importance as embodying real progress. When we know that to be the case, we welcome the new, not because it is merely new, but because it is a substantial addition to what is already known to be a good. But, on the other hand, much that is novel in opinion is novel only as the latest change of the weather is new. And I warn you, not indeed blindly to condemn, but cautiously to suspect doctrines that are obliged to advertise, very ostentatiously, the supposed fact that they are new, in order to get a public hearing. In really progressive sciences, as for instance in psychology itself, the most important advances need not be thus loudly heralded. They make their own way, not because they are merely new, but because they are maturely conceived and carefully worked out. As for the world of faith, it is as vain to be a mere seeker of novelties as it is to be a mere conservative. In our deeper faiths the newest and the oldest of humanity's deeds, interests, and experiences lie side by side. What is new for one soul is not new for another. Love and death and our duty, these are the oldest and the newest things in human destiny. The new love is not on that account the true one. The new coming of death teaches still the ancient lessons of the burial psalm. 
The new duty is no duty unless it is an example of the most venerable of truths. "These things" says Antigone, "are not of to-day or of yesterday, and no man knows whence they came." As a fact, what you and I really most need and desire is not the new, nor yet the old. It is the eternal. The genuine lover of truth is neither a conservative nor a radical. He is beyond that essentially trivial opposition. He cares nothing for the time in which these things came to pass. For him their interest lies in their truth. Time is but an image, an imitation of the eternal. Evolution itself is only a fashion in which the everlasting appears. For God there is nothing new. Before the mountains were brought forth, or ever thou hadst founded the earth, from everlasting thou art God.

Be docile then; be ready to learn what is new to you. But avoid this disease of merely running after every thought that loudly proclaims, or every plan that stridently asserts, "Behold, I am new." Say to every such claimant for your reverence: "Are you such that you can grow old and still remain as good as ever? Then indeed I will trust you."

But is there nothing, then, in the idea of progress? Are there not certainly progressive moments, whose new stages will therefore be good? Yes. The actual discoveries of empirical science, once submitted to careful test, do indeed form a progressive series. Here the new, once assured by critical verification, is good. But the existence in any particular field of inquiry or of action of a progress that you and I can regard as certain, is never something to be merely presumed. The presumption is valid only after due examination. Only the expert can decide then, with clearness, whether the new is good. This holds in finance and in business as genuinely as in politics or in religion. Therefore it is only, once more, within the relatively narrow range of your expertness, that you can judge whether the new really is, as such, likely to be the good. Outside of that range, favor no novelties unless they appeal to your personal sentiments, to your most humane sympathies, to your best cultivated, but still in general partly unconscious, tastes and instincts. In brief, then, I say to our thoughtful public, overcome your limitations, first by minute and faithful study of a few things and by clearness of ideas about them; then by childlike simplicity in the rest of life, by faithfulness to enlightened leaders, by resignation as opposed to restlessness, and above all by 
1134 COMMUNITY AS LIVED

work rather than by idle curiosity. Organize through a willingness to recognize that we must often differ in insight, but that what we need is to do something together. Avoid this restless longing for mere novelty. Learn to wait, to believe in more than you see, and to love not what is old or new, but what is eternal. 